\title{
The Dry Puna as an ecological megapatch and the peopling of South America: Technology, mobility, and the development of a late Pleistocene/early Holocene Andean hunter-gatherer tradition in northern Chile
}

Daniela Osorio a, b, *, James Steele a, Marcela Sepúlveda c, Eugenia M. Gayo d, e, Jose M. Capriles f, Katherine Herrera b, g, Paula Ugalde b, h, Ricardo De Pol-Holz i, Claudio Latorre j, k, Calogero M. Santoro b

a Institute of Archaeology, University College London, 31-34, Gordon Square, London, WC1H 0PY, United Kingdom

b Laboratorio de Arqueología y Paleoambiente, Instituto de Alta Investigacion, Universidad de

Tarapaca, Antofagasta 1520, Casilla 6-D, Arica, 100236, Chile

c Laboratorio de Analisis e Investigaciones Arqueometricas, Laboratorio de Arqueología y

Paleoambiente, Instituto de Alta Investigacion, Universidad de Tarapaca, Antofagasta 1520, Casilla 6-

D, Arica, 100236, Chile

d Departamento de Oceanografía, Universidad de Concepcion, Barrio Universitario s/n, Concepcion,

Chile

e Center for Climate and Resilience Research (CR)2, Blanco Encalada, 2002, Santiago, Chile

f Department of Anthropology, The Pennsylvania State University, University Park, PA, 16802, USA

g UMR "Prehistoire et Technologie" de la Maison Rene Ginouves, Universite Paris X-Nanterre, 200

avenue de la Republique, 92001, Nanterre Cedex, France

h School of Anthropology, University of Arizona, Tucson, AZ 85721-0030, USA

i GAIA-Antartica, Universidad de Magallanes, Punta Arenas, Chile

j Departamento de Ecología y Centro UC Desierto de Atacama, Pontificia Universidad Catolica de

Chile, Alameda 340, Santiago, Chile

k Instituto de Ecología y Biodiversidad (IEB), Las Palmeras, 3425, Santiago, Chile

* Corresponding author. Institute of Archaeology, University College London, 31-34, Gordon Square, London, WC1H 0PY, United Kingdom.

-mail addresses: daniosorio8@gmail.com, daniela.osorio.15@ucl.ac.uk (D. Osorio).

A B S T R A C T. Current scientific evidence shows that humans colonized South America at least 15,000 years ago, but there are still many unknown aspects of this process, including the major and minor migratory routes involved, and the pattern of successive occupation of a diverse continental mosaic of ecosystems. In this context, the role of the Andean highlands ( 3400 meters above sea level) has been neglected, because of the supposedly harsh conditions for humans including hypoxia and cold climate. Nevertheless, the environmental and cultural resources available in the high Andes constitutes an important "megapatch" that should be assessed in terms of human settlement patterns. We review the evidence for late Pleistocene/ early Holocene hunter-gatherer occupation of one part of this megapatch, the northern Chilean Dry Puna, in its palaeoecological context. We focus on lithic technology, faunal remains, radiocarbon dates, and other archaeological materials related to different social activities, which allow us to suggest that groups of hunter-gatherers organized and adapted their way of life to highland ecosystems through logistical mobility, and curatorial strategies for lithic tool kits that included projectile points and other formalized tools. The morphology and technological processes involved are recognized over vast territories along the high Andes. We identify this material expression as the high south central Andean Archaic hunter-gatherer tradition, which also featured long distance mobile settlement systems and communication processes over this broad and distinct megapatch. More speculatively, we outline the hypothesis that these highland ecosystems constituted a suitable migratory route that may have been key for the early peopling of the continent, and contrast it with the alternative hypothesis of the initially secondary and seasonally intermittent exploitation of this habitat by hunter-gatherers dispersing along the Pacific coastal corridor. 


\section{Introduction}

The south central Andean highlands ( $>2500$ metres above sealevel [masl], latitudinal range 16-25 deg. S, which encompasses southern Peru, northern Chile and north-western Argentina, Santoro, 1989), like other high altitude environments, are regions with marked ecological gradients where plant and animal communities vary markedly over relatively short distances (Aldenderfer, 1998, 1999, 2006, 2008; Santoro and Nunez, 1987). Ecologically, on the western Andean slope the 2500 masl boundary between the highlands and lowlands generally coincides with dramatic shifts in precipitation that bring about large differences in vegetation and in animal adaptations (Arroyo et al., 1988; Luebert and Pliscoff, 2006). Above 2500 masl, physiological processes related to hypoxia (or decrease in oxygen availability) can affect humans as well as plant and animal populations, due to a reduction in barometric pressure at greater altitudes (Behn et al., 2007; Llanos et al., 2007). Thus, steep relief, low temperatures and hypoxia characterize the ecology of highland landscapes in the following ways: (a) environmental heterogeneity, (b) low predictability (high instability), and (c) low primary productivity (Aldenderfer, 1998). These harsh environmental conditions have led researchers to overlook the Andean highlands as a potential early migratory route and as suitable habitat for the initial human colonization of South America (Bird, 1943; Lanning, 1967; but see Santoro and Nunez, 1987; Santoro, 1989). Archaeological narratives of the region typically begin in the Holocene with Archaic societies, ca. 10,000 years ago (Aldenderfer, 2008).

Recent discoveries of very early sites located in the highlands of Peru (Cuncaincha, at 4400 masl, dated between 12.8 and 11.5 cal. kyr BP; Rademaker et al., 2014) and of Bolivia (Cueva Bautista, at 3900 masl, dated between 12.9 and 12.6 cal. kyr BP; Capriles and Albarracín-Jordan, 2013; Capriles et al., 2016) have challenged this perception of the earliest settlement of the high Andes. Given this new evidence, models of how the highlands were peopled are also being r-evaluated. One proposal which we advance here relates to whether this whole high south central Andean sierra/dry puna region represented an ecological high Andes 'megapatch' (a term introduced by Beaton, 1991) with a dispersed but interconnected hunter-gatherer settlement system extending as far north as the highland of the Peruvian Central Andes (where comparable biomes are found in the Pampa de Junin, $11 \mathrm{deg} \mathrm{S}$, the punas of Ancash, 8-9 deg S, and the Cajamara puna, 7 deg S; K. Rademaker, pers. comm.). Another ongoing debate relates to the possibility of a late Pleistocene dispersal corridor across this predominantly north-south oriented South America megapatch, accompanying the Pacific coastal corridor hypothesis that is a familiar element of initial colonization models (Sandweiss, 2008). Validation of the Andean megapatch would not, in itself, prove its use as an initial dispersal corridor. However, validation of the initial dispersal corridor hypothesis would necessarily support the megapatch hypothesis, since part of the definition of a dispersal corridor is that it represents a continuous area of exploitable habitat.

In this paper, we discuss evidence from the five earliest known archaeological sites in the highlands of northernmost Chile at the South Central Andes, which date to the terminal Pleistocene/early Holocene (ca. 12.0-9.5 cal kyr BP) (Fig. 1). In introducing these sites into the discussion of the role of early high altitude settlement in the peopling of South America, we propose also to explore the first of the above two hypotheses, namely that the Andean highlands may have constituted an important megapatch and that the material culture of these sites was part of a region-wide cultural tradition and settlement system. This paper thus 
complements previous work regarding specific mobility strategies engaged by early huntergatherers in northern Chile (Osorio et al., 2017).

\subsection{The south central Andean dry puna as a megapatch}

We suggest that the south central Andean high puna can be considered a megapatch, as defined by Beaton (1991). Beaton derived the concept from the patch choice model in classical foraging theory (e.g. Pyke et al., 1997), where it complements the diet-breadth model by predicting how movement by foragers will occur between circumscribed areas with specific resources (patches). On a larger spatial scale, regions with a resource structure distributed across many rather homogeneous patches, but which appear, in a coarser grain, homogeneous in relation to a given cultural tradition of resource exploitation can be considered as 'megapatches'. This notion differs somewhat from the ecological concepts of 'biomes' (plant and animal communities determined by climate) and 'ecoregions' (geographically continuous instances of particular biome types), by being additionally defined with relation to a specific set of human foraging goals. It has significance in two distinct contexts here: firstly, in enabling us to predict that an ecosystem such as the high Andean puna may have supported a widespread tradition of hunter-gatherer adaptation after initial occupation; and secondly, in enabling us to speculate that such an ecosystem, with its predominant North-South axis, may also have facilitated dispersal and range expansion.

Beaton's own focus (1991:220) was on the colonization of continents, and he only loosely identified several possible types of megapatch: "coasts, mountains, plains, forests, deserts, riverine courses, etc." He also suggested that colonization would typically first occur in 'preferred habitats' such as coasts and river valleys, only later expanding into other kinds of habitat that required significant new adaptations. Others have subsequently emphasized that during range expansion, knowledge acquired locally by hunter-gatherers about animal and plant characteristics could have been transferred to unfamiliar landscapes within a megapatch, minimizing the demands for landscape learning (Kelly, 2003; Meltzer, 2003; Rockman, 2003). Confining movement within megapatches, therefore, would have allowed successful and more or less continuous dispersal (Borrero, 2015). Examples of them which have been explicitly identified as such by other authors in the context of early peopling of the Americas include: the Pacific rim coastal corridor (e.g. the Kelp Highway hypothesis, Erlandson et al., 2007), the Great Plains and other regional biomes of North America (Meltzer, 2004), ecorefugia of North American megafauna linked to terminal Pleistocene climatic stress (Haynes, 2013), and in the southern cone of South America, the xeric steppe and the temperate evergreen forests of Patagonia (Borrero, 2005).

For the South Central Andes and their western coastal margins, an influential hypothesis asserts that initial dispersal followed the coastal corridor, with subsequent expansion into high altitude ecoregions - initially on an intermittent or seasonal basis (Aldenderfer, 1998; Sandweiss, 2008). The first half of this argument has been seen as supported by radiocarbon evidence for a lag in radiocarbon ages for early sites in the montane as compared with the coastal regions (Aldenderfer, 1998; Sandweiss et al., 1998). This has then led to the expectation that initial expansion into high altitudes would have been for occasional, or at most seasonal, hunting expeditions. Aldenderfer (1999/2000: 85), for example, suggests that in mountain environments. "Mobility should be logistical in form, with relatively few 
residential moves on an annual or seasonal basis. In temperate mountain environments, highelevation land use will be limited to the late spring through early fall months since temperature and climate are too extreme for permanent habitation. Foragers will move to lower-elevation base camps during the winter. High elevation land use during the late spring through early fall will be characterized by some residential mobility as foraging groups move into the highlands to exploit newly-available resources. The degree of residential mobility will depend on specific resource configurations, while the size of the foraging group and whether or not it disperses into smaller units depends on resource density, abundance, and distribution." Aldenderfer (1999/2000) also suggests that the archaeological record points to a fairly rapid adaptive shift to permanent occupation of Andean high altitude environments within 500 years of initial exploration, with the coastal ecosystems subsequently no longer included in these montane foragers' annual subsistence circuits. An implication would then be that this also marked a shift from exploitation of ecologically complementary zones by seasonal mobility, to one involving more complex kinds of social alliance and exchange, that enabled all groups to develop more fin-grained local adaptations. This change should have been reflected in a more permanent occupation of the highlands, with the localisation of residential camps near high-quality resource patches, to increase the efficiency of the subsistence effort of these hunter gatherer groups (Aldenderfer, 1998).

In considering the macro-regional similarities in the technology among the early Andean hunter-gatherer sites, we therefore propose that adaptation to the permanent occupation of the highlands can be most easily reconstructed by focusing on sociocultural traditions found within the highland region itself. The coast and the lowlands remained interconnected but socioculturally distinct. We propose that archaeological correlates of long-term adaptation to a megapatch must include not just evidence for its permanent occupation, but also evidence for a focus on particular resources coupled with the necessary technological strategies for resource acquisition and processing. We expect that such a strategy is likely to lead to some degree of mapping of the demographic structure of hunter-gatherer populations onto the mega-patch and its boundaries, such that there is also likely to be homogenization of cultural traditions and social systems. In contrast, we do not expect that occupation of a megapatch should always correlate with a consistent pattern of lithic raw material procurement, nor with a consistent preference for campsite location at specific kinds of landscape features (e.g. rock shelters vs. open air sites), because raw material and natural shelter availability will also be affected by physical and chemical variation in bedrock and surficial geology.

\section{Regional environmental characteristics, past and present}

The Andean orographic effect creates severe environmental conditions for human activities across the steep relief that rises abruptly from the Pacific coast to the Altiplano. Atmospheric pressure drops logarithmically with altitude (West, 2004) and temperature decreases at a predictable rate of 0.0065 _C $/ \mathrm{m}$ (Petersen and Pellicciotti, 2011). Conversely, the rainshadow imposed by high Andean ridges to humidity from eastern South America (Garreaud et al., 2003; Vuille and Keimig, 2004) creates a strong gradient that ranges from semi-arid conditions $>5000$ masl $(\sim 300 \mathrm{~mm} / \mathrm{yr})$, to arid conditions at 4000 masl $(<100 \mathrm{~mm} / \mathrm{yr})$ and finally to hyperarid conditions ( $<5 \mathrm{~mm} / \mathrm{yr}$ ) below 2500 masl (Houston and Hartley, 2003). 
Prevailing cold-xeric conditions constrain the presence of any glaciers to the highest ridges (>5000 masl, Amman et al., 2001) and hillslope vegetation grows at elevations above 2500 masl up to 5000 masl (Gajardo,1994; Arroyo et al.,1988). Indeed, following the elevation, rainfall, and temperature gradients, primary productivity peaks at mid-elevations (3300-4000 masl), and declines as aridity (or adiabatic cooling) increases at lower (or higher) elevations (Villagr_an et al., 1983; Arroyo et al., 1988). Localized groundwater and superficial discharges sustain dense and highly productive Andean peat-bogs (bofedales) between 3400 and 5000 masl (Squeo et al., 2006). These peat-accumulating wetlands have provided key ecosystem services by sourcing fresh-water, fuel supply, wild faunal resources (i.e. birds and small rodents) and grazing habitats for domestic and wild herds (Squeo et al., 2006; Patty et al., 2010; Salvador et al., 2014).

Aridity and extreme minimum temperatures at high elevations are exacerbated south of 20 deg S, defining the transition between the wetter-temperate Dry Puna (16-20 deg S) and the cold-drier Salt Puna (20-25 deg S) eco-regions (Troll, 1958; Santoro and Nunez, 1987). Tussock grasses associated with cushion-plants and sparse shrubs prevail in both eco-regions. Nevertheless, these differ considerably in species composition and ecosystem properties. Grassland and steppe bioproductivity as well as the extent of bofedales are greater in the Dry Puna (Villagr_an et al., 1983; Arroyo et al., 1988; Nunez and Santoro, 1988). Although edible fruits are lacking, the Dry Puna has constituted a favourable productive environment for permanent human settlements at elevations $>4000$ masl. Today, existing high-elevation households are occupied year-round, with reliance on agriculture activities as high as 4000 masl and camelid pastoralism complemented by seasonal herd mobility to lower elevations in the late austral summer and fall (Nú nez and Santoro, 1988).

The western Andean slope underwent two protracted positive hydroclimate anomalies (Fig. 2) at 18.1-14.1 cal kyr BP and 13.8-9.7 cal kyr BP as hydrological budgets increased over a vast area of the south central Andes (16-25 deg S) at the end of the last glacial period. Together, these millennial-scale variations in the regional hydrological cycle are part of the Central Andean Pluvial Event (CAPE I and CAPE II, Latorre et al., 2006; Quade et al., 2008; Placzek et al., 2009; Gayo et al., 2012; further investigation should reveal the extent of any spatially lagged responses and/or differential sensitivity of local circulation patterns to these disruptions in the Andean climate system).

Substantial evidence indicates that the CAPE stages profoundly affected the potential for early hunter-gatherer settlement by increasing the availability of hydrological and biotic resources across the arid Andes (Moreno et al., 2009; Santoro et al., 2011; Gayo et al., 2012; Latorre et al., 2013). For instance, wetter conditions led to a prominent lacustrine transgression on the Uyuni basin (Placzek et al., 2006, 2013; Blard et al., 2011) and other minor high-elevation basins (Geyh et al., 1999; Grosjean et al., 2001; Bao et al., 2015) during the Tauca (18.1-14.1 cal kyr BP) and Coipasa (12.8-11 cal kyr BP) lake highstands.

Concomitant glacier advances, implying a snowline depression of up to $1000 \mathrm{~m}$, occurred on the Bolivian Altiplano apparently brought about by a precipitation intensification of at least $250 \mathrm{~mm} / \mathrm{yr}$ and $>4 \mathrm{deg} \mathrm{C}$ cooling (Blard et al., 2009, 2013; Placzek et al., 2013). Similarly, positive rainfall anomalies enhanced groundwater and superficial discharge along Andean catchments (Rech et al., 2003; Nester et al., 2007; Quade et al., 2008; Gayo et al., 2012; Schittek, 2014; Saez et al., 2016; Veit et al., 2016), which in turn could have amplified the extension and bioproductivity of fertile environments for human activities (i.e. bofedales). 
Moreover, moister conditions promoted significant increases in the availability of plant resources for livestock at lower elevations as evinced by elevational displacements of hillslope vegetation and reconstructed plant-cover for Andean grasslands (Maldonado et al., 2005; Latorre et al., 2006; Quade et al., 2008; Placzek et al., 2009; Mujica et al., 2015).

\section{Archaeological evidence for early occupation of the Dry Puna: the north Chilean case}

We now review the archaeological record of early human settlements of the Andean highlands, focusing on the Dry Puna of northern Chile. We define the technological features of the lithic assemblages, complemented with descriptions of other components found in the camps such as faunal remains and ochre pigments. Our megapatch model predicts the development of a cultural tradition with consistent attributes within a fairly homogeneous resource zone.

Our case study includes the five earliest sites that have been found in the Dry Puna of northern Chile, located between 3100 and 4500 masl, in the Arica and Parinacota Region (18$19 \mathrm{deg}$ S). These sites are Las Cuevas, Hakenasa, Patapatane, Pampa El Muerto 15, and Ipilla 2 (Fig. 1, Table 1), We have analyzed material from the earliest stratigraphic levels of these sites, which are dated to the Pleistocen-Holocene transition (ca. 11.5-9.0 cal kyr BP). The five sites presented here can be split into three groups: the oldest sites located above $4000 \mathrm{~m}$ (Las Cuevas and Hakenasa) were occupied during CAPE II, whereas the younger sites are located below 4000m(Patapatane, Ipilla 2) and postdate the CAPE II event (Fig. 2). The third group composed by Pampa El Muerto 15 falls in between these upper and lower elevation sites and is intermediate in age (10.7 cal kyr BP). Previous studies on these and other Andean sites focused on lithic technology and faunal assemblages, which were then used to discuss mobility strategies using classic models such as transhumance, cyclical mobility, and sedentism, or newer behaviorist approaches (Niemeyer and Schiappacasse, 1963; Cardich, 1964; Lynch, 1971; Rick, 1980; Santoro and Nunez, 1987; Aldenderfer, 1998; Osorio et al., 2017).

The total study sample, obtained from the earliest levels of these five sites, is composed by 3848 fragments of faunal remains and 4446 specimens of lithic artifacts (Table 2). For bone assemblages we used standard zooarchaeological techniques and classified the material to the highest taxonomic and anatomical resolution that their condition permitted (Lyman, 1994; Reitz and Wing, 2008). Cultural and non-cultural modifications were also recorded. Lithic technological analyses included both the debitage and the tools (defined by the presence of retouch or of used edges), with a main focus on identifying reduction sequences (Andrefsky, 2005, 2008; Aschero and Hocsman, 2004). The highest-level descriptive variables recorded were raw material, type and size of debitage, presence of cortex, and type of platform. We also classified sites by function (residential or logistical, Binford, 1979, 1980; Nelson,1991) and by technological strategy (Bamforth, 1986; Nelson, 1991; Shott, 1996), using the criteria of Binford (1979, 1980), Nelson (1991), and Aldenderfer (1998). The presence of logistical sites would allow us to define a collector mobility strategy, which differs (along a continuum) from the forager mobility strategy. The main difference between the two is that in a forager system, hunter-gatherers maintain high residential mobility (movement of the complete group from one camp to another) with fewer logistical movements (movement of specific task groups out from the camp that then come back), whereas in a collector system, hunter- 
gatherers make fewer residential movements and invest more effort in logistical forays (Kelly, 1995).

\subsection{Faunal assemblages}

The faunal assemblages were dominated by artiodactyls, especially camelids (guanaco and vicuna), in all five sites (see Osorio et al., 2017). Also present were a few deer bones (probably Hippocamelus antisensis) at Hakenasa. Other identified taxa include medium-sized rodents such as vizcachas (Lagidium), wild guinea pig (Cavia) and cholulos (Ctenomys, a small Andean mammal similar to the North American gopher in its burrowing habit). Many bones are burnt or have breakage patterns consistent with human consumption (Supplementary Information, Fig. S1).

Birds were also present, and although they were not identified to genus, most correspond to medium-sized ducks and coots. Exotic faunal remains are very scarce; for example, two shark teeth were identified in Las Cuevas and Ipilla 2, and unidentified fish bones from the Pacific Ocean and mussel shell (Choromitylus) fragments (three of which show evidence of edge retouch) were found in Patapatane.

\subsection{The lithic assemblages (see also Osorio et al., 2011; Herrera et al., 2015; Santoro et al., 2016; Osorio et al., 2016)}

A large variety of lithic raw materials were recorded and can be grouped into five general categories (siliceous rocks, obsidian, basalt, sandstone and other rocks) with a predominance of high quality siliceous rocks. The siliceous rocks found in the two oldest and highest sites, Las Cuevas (11.5 cal kyr BP) and Hakenasa (10.9-11.3 cal kyr BP) must have been transported from lower elevations, which required journeys of at least 30 to $40 \mathrm{~km}$. The younger sites (Pampa El Muerto 15, 10.7 cal kyr BP; Ipilla 2, 10-9.4 cal kyr BP, and to a lesser degree Patapatane, 9.4-9.0 cal kyr BP), are located close to seasonal watercourses where nodules of siliceous rocks adequate for knapping are readily available (Table 3 ).

Obsidian, which is abundant in Hakenasa and Las Cuevas, was probably transported from the relatively close Chara na and Parinacota sources, both of which are currently under study by our research group. Small nodules $(<5 \mathrm{~cm})$ mixed-in with surface gravels and consistent with the size of artifacts are common near these sites, and occur throughout the Altiplano. In contrast, obsidian is exotic at the three younger sites, where it is also infrequent in the lithic assemblages.

Debitage dominates the lithic assemblages ( $\sim 98 \%)$ and mostly derives from late, and to a lesser extent, middle stages of reduction of mainly bifacial and in less degree unifacial tools. Most of the observed debitage (Table 4) is characterized by the absence of cortex (81-98\%), small size $(<20 \mathrm{~mm})$, and a preponderance of broken, reduced and flat platforms (Inizan et al., 1999; Duran and Soler, 2006). We also found bifacial trimming flakes with faceted or "complex" platforms, lips, flake curvatures, and dorsal scars in different directions (Andrefsky, 2005) (Fig. 3). We also found some evidence of probable heat treatment in some 
of the siliceous debitage in Hakenasa, and we found small fragments of red pigment at Las Cuevas and Patapatane.

Together, these attributes and the absence of complete cores suggest that the activities consisted primarily of shaping and reactivating instruments, and secondarily of bifacial reduction. Only four fragments of exhausted cores were observed in Hakenasa. The lithic debitage from Patapatane and Ipilla 2 mainly corresponds to retouching debitage and, to a lesser extent, to flakes and other fragments. Most of the lithic debitage does not include cortex (Fig. 4) and is of small size $(<20 \mathrm{~mm})$. These features are also indicative of the final stages of the reduction sequence. Most of the lithic tools were highly standardized and maintained, which is consistent with the high frequency of retouching flakes recorded (Fig. 4). Projectile points are the most frequently observed instrument, but they are only present in three of the studied sites (Patapatane, Hakenasa and Ipilla 2), and correspond to five morphological types: stemmed with shoulders (known as Patapatane); triangular with either straight, convex or concave base; and tetragonal. Many of these projectile points have evidence of maintenance by $r$-sharpening of the edges, and some of them show evidence of recycling (Osorio et al., 2011; Herrera et al., 2015). At Patapatane and Hakenasa, projectile point preforms and abundant debitage are also present, all indicative of final stage manufacturing processes.

Side scrapers are the most abundant tool at Hakenasa: their forms are simple or double convex and show high standardization and maintenance. Scrapers (semidiscoidal and end scrapers) are very common and highly maintained. In lower frequencies we found hammers at Patapatane and Ipilla 2, and small core fragments in Hakenasa. Unstandardized or expedient tools are extremely rare, and correspond to utilized flakes in Ipilla 2 and retouched flakes in Pampa El Muerto 15. The latter site also includes one notched tool, possibly related to processing plants (Winchkler, 2006; Hocsman, 2009; Osorio et al., 2016).

In terms of site function, some formal tools at Hakenasa show macroscopic wear traces on their active edges and were possibly used for hunting animals as well as processing hides and meat. The frequency of projectile points, scrapers, side scrapers and knives, suggest animal procurement and meat and hide (and to a lesser extent, plant) processing activities, which is consistent with the abundant faunal remains, especially camelids, found in association with the stone tool assemblages.

Similarly, at Las Cuevas we recognized a predominance of final stages of formalization, $r$ sharpening of worn edges and to a lesser extent, bifacial knapping. The instruments are scarce and suggest activities related to scraping and to tool maintenance. At Ipilla 2, the predominance of medium and mostly final stages of reduction, especially of bifacial artifacts, as well as knives and side scrapers, indicate diverse activities such as hunting, animal processing, and probably leather scraping. There are also a few expediently utilized flakes (with macroscopic wear traces), and a denticulate scraper possibly used in woodwork. At Pampa El Muerto 15, the site with the most ephemeral occupation, knapping activities, shown by instruments and debitage were rare, and were related to final stages of tool manufacture, and to cutting and processing meat and other soft materials such as plants. 


\section{Discussion}

\subsection{Interpretation of site function}

We interpret the analysed sites as temporary logistical camps (Binford, 1980) as suggested by the quantity and characteristics of the lithic assemblages, which were focussed on final stages of lithic reduction sequences for formalization or reactivation of worn edges, and by the absence of more elaborated features like hearths. The almost exclusive use of high quality raw materials, the small size of the tools, their standardized forms, and the changes in their morphologies due to rejuvenation, are all attributes of a curatorial strategy. The tools recorded in the five studied sites were transported by hunter-gatherers in their mobility circuits and were not initially elaborated in situ. The identification of bifacial trimming flakes shows bifacial reduction, which is also an element of a curated system, reflecting those tools' flexibility and transportability (Shott, 1986; Kelly, 1988). In this way, hunter-gatherers anticipated, mitigated, and minimized risks of possible adverse conditions, like the absence of good raw materials, or insufficient time for manufacturing tools at moments where they needed them (Nelson, 1991). The specific strategy for facing these difficulties is to invest more energy in the manufacturing of the artefacts, and the transportation of a toolkit elaborated in advance.

Risk minimisation, a crucial element in the process of colonization of new landscapes (Meltzer, 2003) has been especially emphasized by Aldenderfer (1998) for the early occupation of a mountain environment. Due to the extreme conditions of the highland ecosystem (low temperatures and hypoxia), hunter gatherer decision-making would have been guided by the need to reduce effort in obtaining a sufficient caloric return (Aldenderfer, 1998, 1999). In the scenario of an early first entry into highland zones, curation and versatility of the tool kit would have been an essential strategy for an effective settlement process.

The two earlier sites located $>4000 \mathrm{~m}$ in the Dry Puna (Las Cuevas and Hakenasa) are both interpreted as logistical camps. Las Cuevas has a briefer occupation with minimal processing of formalized instruments, and could be related to the initial phase of exploration of new areas. The absence of projectile points may indicate that hunting activities were carried out elsewhere. Hakenasa Cave, some $35 \mathrm{~km}$ away, has evidence of multiple activities (hunting, processing of animals, and final manufacturing of the instruments).

The second and later group of sites, Papatapane and Ipilla 2, show striking similarities, including final stages of the lithic reduction sequence. The difference with the earliest sites, however, is the presence of more diverse activities, especially in Patapatane (hunting, scraping, processing animals, among others). Such diversity could be due to either longer stays at the sites, or to frequent visits to the site over a short time period (the two earliest ${ }^{14} \mathrm{C}$ dates from Patapane, Beta-238852 and I-12837 are statistically indistinguishable by Ward \& Wilson's test, $\mathrm{p}>0.05, \mathrm{~T}=0.64, \mathrm{X} 2=3.84)$.

The appearance of some exotic materials in Las Cuevas (shark teeth) and Patapatane (fish bones and shells) suggests the existence of inter-regional exchange with other groups. Such exotic elements can contribute to identifying interaction between different bands, or social differentiation within groups (Castillo and Sepúlveda, 2017). Additionally, the presence of probable bone beads in Hakenasa and red pigments in Las Cuevas are key indicators of social 
activities that went beyond hunting and procurement of raw materials. Indeed, the absence of a specific theoretical framework for early colonizing strategies that can predict the use of such "rare" materials, reveals the over-simplification of explanations for early hunter-gatherer societies which focus solely on economic and technological aspects (Miotti, 2003). In more recent times, although only one piece of painted rock has been identified for the late Archaic Period in Patapatane, rock art of a naturalistic tradition can be encountered, without major stylistic changes, from the end of middle Archaic (6.7 cal kyr BP) up to the Formative periods (ca. 1.3 cal kyr BP) in the region (Sepúlveda et al., 2017). This tradition is shared by the highlands of the southern Peru and northernmost Chile (Sepúlveda et al., 2013), demonstrating a flow of information between hunter-gatherer groups at a large spatial scale and the creation of territories with specific symbolic landmarks. Economic intensification and social complexity created cultural landscape linked to a naturalistic rock art tradition, which is coincident with specific territories in the Dry Puna megapatch. This traditional symbolic practice stemmed from a long-term history of hunter gatherer adaptation inside this high Andean region.

\subsection{Wider cultural relationships and implications for the Dry Puna megapatch model}

To further evaluate the earliest evidence for such large-scale interactions, we looked at the lithic record in wider comparative perspective within the south central Andean highlands. We note remarkable similarities among formal tool types present at Hakenasa, Patapatane, and Ipilla 2 (all dated to 11.3-9.5 cal kyr BP), and at sites located in the Peruvian highlands ( 12.8-9.0 cal kyr BP). For instance, the triangular unstemmed projectile points found in Hakenasa and Patapatane (Fig. 5: 1, 19, 20) are also found in the earliest levels at Pachamachay (Rick, 1980). However, the most common element shared between the sites from northernmost Chile and the assemblages of other early Andean highland sites is the stemmed point with shoulders known as a "Patapatane" projectile point type (Fig. 5: 1,19, 20; Santoro,1989; Osorio et al., 2011). Its morphology is similar to the point Type 1A, defined by Klink and Aldenderfer (2005) at Asana and Caru (Ravines, 1967; Aldenderfer, 1998). Similar point shapes occur at Telarmachay (Lavallee et al., 1995), Pachamachay (Rick, 1980), Lauricocha (Cardich, 1958), and Guitarrero Complex 2 (Lynch, 1980) in the central Peruvian Andes (see Fig. 5). The similarities are identified mainly in the morphology of the stems, and the maintenance of shoulders or barbs even when the projectile points were reactivated. It seems possible to identify a change in shape with use: probably the projectile point initially had barbs, which would have changed to shoulders because of the reactivation process (cf. Hoffman, 1985; Shott and Ballenger, 2007). Additionally, the overall geometry also changed, moving from convex edges and more elongated blades, to straight edges and shorter blades, producing a triangular morphology (Fig. 5: 11, 13, 14).

Stylistic similarities in projectile point form, when defined by a diagnostic morphology and technology of production that represents more than archaeologists' essentializing of a midpoint on some continuum, may arise and persist by repeated and conservative cultural transmission within social networks or groups. These distinctive characteristics may arise and persist simply through cultural drift due to partial population isolation, or they may be maintained as active signals of social identity (Close, 1978; Meltzer, 1981; Sackett, 1982; Wiessner, 1983; Wobst, 1999). The Patapatane type is therefore informative as a cultural tradition and potentially as a symbolic resource, which indicates the existence of wider 
networks of social relations between dispersed and highly mobile groups involved in different kinds and scales of social interaction and exchange (and as a minimum, the transfer of knowledgeable people between local bands). If an active signalling function is assigned to the Patapatane type, then this must have extended beyond the smaller-scale 'intimate networks' of local bands where the presence of such symbolic or stylistic resources was not necessary (Gamble, 1998). By implication, the use of a specific type of lithic projectile point was not only a simple tool for hunting, but also a communication device spread over the central Peruvian and south central Andean highland megapatch. This signalling of cultural identity would also formed part of the background for other later communication practices shared across the south central Andean highland megapatch, such as the rock art (already noted above), which show similarities in the represented figures, in its formal and technical features and in the composition of the panels (Sepúlveda et al., 2013, 2017).

\section{Conclusions}

The evidence described and analysed here suggests that the highland sites from northernmost Chile were camps occupied within a logistic mobility system, and coupled with a curatorial tool strategy. The associated residential camps have yet to be found, if indeed they existed at the same elevations in the high Andes. However, we are inclined to suggest that our understanding of the diagnostic signatures of such camps during an initial occupational phase should also be re-evaluated and new models proposed, especially for interpreting differences in lithic assemblages and implied activity patterns at camps that are not captured by the simple dichotomy of residential and logistic. Indeed, it is possible that the evidence discussed in this paper, which spans a 2000-year time range, reflects neither an initial exploration phase (Borrero, 1989/90) engaged in by transient explorers (Beaton, 1991), nor intermittent hunting expeditions to a familiar but physically difficult environment from base camps at lower elevations. Instead, it could reflect a highland way of life that had developed over generations of permanent occupation within this large megapatch.

Resolving these competing interpretations will require further information on lithic raw material procurement (to establish at which elevation zone the raw materials had been procured), the identification of contemporaneous residential camps of the same cultural tradition, and further information on resource availability and seasonality during the earliest occupation phase in CAPE II. We further note that there are as yet no dated occupations in the Andean highlands (or in all of the central Andes) that date to the CAPE I event, despite abundant evidence for increased available moisture. One possibility is that temperatures may have been simply too cold for human occupation, but this should be tested by seeking new evidence.

Turning more speculatively to the potential of the Andean highlands as a migratory route, we have argued that the highlands of southern Peru and northernmost Chile, which correspond to geographical distribution of the Dry Puna, constitute a rather homogeneous "megapatch" that may have favoured rapid dispersal from north to south (after initial discovery by huntergatherers dispersing inland as well as southwards along the Pacific coast). It may also potentially have provided a habitat 'bridge' to the eastern side of the Andean mountains. Specific ecological conditions during the Pleistocene-Holocene transition may have favoured human occupation of the area, and recent discoveries in the highlands of Peru and Bolivia 
show that parties of hunter-gatherers initiated processes of colonization at much earlier stages than was previously thought. However, resolving the chronology of initial occupation of the South Central Andes and its different altitudinal ecozones, for comparison with the chronology of settlement of the lowlands and coastal margins, will require additional radiocarbon dates from a larger sample of sites.

We propose that the longevity and distinctiveness of the hunter gatherer Andean tradition we see in the Dry Puna megapatch indicates long-term familiarity with and cultural adaptation to the highland landscapes and ecosystem, consistent with permanent occupation (Rick, 1980). The existence of shared ideas and of long distance communication processes may reflect the development of a cultural tradition linked to occupying and appropriating this particular megapatch.

Finally, we contend that the megapatch concept is a useful tool for the analysis of settlement processes on a broad spatial scale (Dixon, 2001), such as the early occupation of South America. We suggest that the ecological and geographical boundaries of the Dry Puna megapatch are reflected in similarities in lithic technology and typology at the sites reviewed in this paper. By contrast, the archaeological records of the Atacama Desert and the Salt Puna, south of the Dry Puna, are completely different in their cultural trajectory, in their lithic assemblages (different technology and projectile point types), and in their paleoenvironmental conditions, which did not favour year-round human occupations (Santoro and Nunez, 1987; Santoro, 1989; Nunez et al., 2005; Osorio et al., 2017). The next step in developing this approach is to specify in greater detail the distinctive cultural traits and the defining ecological characteristics of this Late Pleistocene-Early Holocene Andean megapatch. Furthermore, this zone may not be completely homogeneous: its archaeological variability must also be further explored.

\section{Acknowledgments}

We thank Bonnie Lynn Pitblado, and Kurt Rademaker for inviting us to participate in this special issue of QI, resulted from the "Symposium: The Role of High Altitude Landscapes in the Peopling of the New World". We would also like to thank Paola Salgado for editing the figures. Kurt Rademaker and Mike Shott provided invaluable constructive feedback on an earlier draft. This work was supported by CONICYT/Programa Formacion de Capital Humano Avanzado project 72160203, Grants Sub-Committee Awards, Institute of Archaeology, University College London (DO, JS); FONDECYT grants 1130808 (to MS) and 1160744 (to CMS, EMG, CL), 3140008 (to JMC), 11150210 (to EMG), FONDAP 1511009 to (CR)2, CONICYT/ PIA, Anillo project SOC1405, CONICYT/PCI project PII20150081 (to JMC, CMS, CL), PFB 23 to the IEB (CL) and ICM NC120066 (to CL and RDP).

Appendix A. Supplementary data. Supplementary data related to this article can be found at http://dx.doi.org/10.1016/j.quaint.2017.07.010. 


\section{References}

Aldenderfer, M., 1998. Montane Foragers. Asana and the South Central Andean Archaic. University of Iowa Press, Iowa City.

Aldenderfer, M., 1999. An Archaeological perspective on the human use of cold montane environments in Andean South America. Rev. Arqueol. Am. 17-19, 75-96.

Aldenderfer, M., 2006. Modelling plateau peoples. The early human use of the world's highest plateau. World Archaeol. 38, 357-370.

Aldenderfer, M., 2008. High elevations foraging societies. In: Silverman, H., Isbell,W. (Eds.), Handbook of South American Archaeology. Springer, New York, pp. 131-144.

Amman, C., Jenny, B., Kammer, K., Messerli, B., 2001. Late Quaternary response to humidity change in the arid Andes of Chile (18-29S). Palaeogeogr. Palaeoclimatol. Palaeoecol. 172, 313-326.

Andrefsky, W., 2005. Lithic: Macroscopic Approaches to Analysis. Cambridge University Press, Cambridge.

Andrefsky, W., 2008. Lithic Technology. Cambridge University Press, Cambridge.

Arroyo, M.T.K., Squeo, F., Armesto, J.J., Villagran, C., 1988. Effects of aridity on plant diversity in the northern Chilean Andes: results of a natural experiment. Ann. Mo. Bot. Gard. 75, 55-78.

Aschero, C.A., Hocsman, S., 2004. Revisando cuestiones tipologicas en torno a la clasificacion de artefactos bifaciales. In: Acosta, A., Leponte, D., Ramos, M. (Eds.), Temas de Arqueología: Analisis Lítico. Universidad Nacional de Lujan, Lujan, pp. 725 .

Bamforth, D., 1986. Technological efficiency and tool curation. Am. Antiq. 51 (1), 38-50.

Bao, R., Hernandez, A., Saez, A., Giralt, S., Prego, R., Pueyo, J.J., Moreno, A., ValeroGarces, B.L., 2015. Climatic and lacustrine morphometric controls of diatom paleoproductivity in a tropical Andean lake. Quat. Sci. Rev. 129, 96-110.

Beaton, J.M., 1991. Colonizing continents: some problems from Australia and the Americas. In: Dillehay, T.E., Meltzer, D.J. (Eds.), The First Americans: Search and Research. CRC Press, Boca Raton, Florida, pp. 209-230.

Behn, C., Araneda, O., Llanos, A., Celedon, G., Gonzalez, G., 2007. Hypoxia-related lipid peroxidation: evidences, implications and approaches. Respir. Physiol. Neurobiol. $158,143-150$. 
Binford, L.R., 1979. Organization and formation processes: looking at curated technologies. J. Anthropol. Res. 35, 255-272.

Binford, L.R., 1980. Willow smoke and dog's tail. Hunter-gatherer settlement systems and archaeological site formation. Am. Antiq. 45, 4-20.

Bird, J., 1943. Excavations in Northern Chile. Anthropological Papers of the American Museum of Natural History Volume XXXVIII, Part IV. Nueva York.

Blard, P.H., Lave, J., Farley, K.A., Fornari, M., Jimenez, N., Ramírez, V., 2009. Late local glacial maximum in the central altiplano triggered by cold and locally-wet conditions during the paleolake Tauca episode (17-15 ka, Heinrich 1). Quat. Sci. Rev. 28, 34143427.

Blard, P.H., Sylvestre, F., Tripati, A.K., Claude, C., Causse, C., Coudrain, A., Condom, T., Seidel, J.L., Vimeux, F., Moreau, C., Dumoulin, J.P., Lave, J., 2011. Lake highstands on the Altiplano (tropical Andes) contemporaneous with Heinrich and the younger Dryas insights from 14C, U-Th dating and d18O of carbonates. Quat. Sci. Rev. 30, 3973-3989.

Blard, P.H., Lave, J., Sylvestre, F., Placzek, C.J., Claude, C., Galy, V., Condom, T., Tibari, B., 2013. Cosmogenic $3 \mathrm{He}$ production rate in the high tropical Andes $(3800 \mathrm{~m}, 20 \mathrm{~S})$ : implications for the local last glacial maximum. Earth Planet. Sci. Lett. 377-378, 260275.

Borrero, L.A., 2005. The archeology of the Patagonian deserts hunter-gatherers in a cold desert. In: Veth, P., Smith, M., Hiscock, P. (Eds.), Desert Peoples, Archaeological Perspectives. Blackwell Publishing, New York, pp. 142-158.

Borrero, L., 2015. Moving: hunter-gatherers and the cultural geography of South America. Quat. Int. 363, 126-133.

Castillo, C., Sepúlveda, M., 2017. Objetos "miscelaneos" y dinamicas sociales en contextos cazadores recolectores de la precordillera de Arica, extremo norte de Chile. Chungara Rev. de Antropol. Chil. 49, 159-174.

Capriles, J.M., Albarracin-Jordan, J., 2013. The earliest human occupation in Bolivia: a review of the archaeological evidence. Quat. Int. 301, 46-59.

Capriles, J.M., Albarracin-Jordan, J., Lombardo, U., Osorio, Daniela, Herrera, K.A., Maley, B., Goldstein, S.T., Domic, A.I., Glascock, M.D., Veit, H., Santoro, C.M., 2016. High-altitude adaptation and late Pleistocene foraging in the Bolivian Andes. J. Archaeol. Sci. Rep. 6, 463-474. 
Cardich, A., 1958. Los yacimientos de Lauricocha: nuevas interpretaciones de la prehistoria peruana. Studia Praehistorica I. Centro Argentino de Estudios Prehist oricos, Buenos Aires.

Cardich, A., 1964. Lauricocha: Fundamentos para una Prehistoria de los Andes Centrales. Studia Prehistorica III. Centro Argentino de Estudios Prehistoricos, Buenos Aires.

Close, A.E., 1978. The identification of style in lithic artefacts.World Archaeol. 10 (2), 223237.

Duran, J.-P., Soler, N., 2006. Variabilite des modalites de debitage et des productions lithiques dans les industries mousteriennes de la grotte de l'Arbreda, secteur alpha (Serinya, Espagne). Bull. de la Societe Prehistorique Française 103, 241-262.

Dixon, E.J., 2001. Human colonization of the Americas: timing, technology and process. Quat. Sci. Rev. 20, 277-299.

Erlandson, J.M., Graham, M.H., Bourque, B.J., Corbett, D., Ester, J.A., Stenck, R., 2007. The kelp highway hypothesis: marine ecology, the coastal migration theory, and the peopling of the Americas. J. Isl. Coast. Archaeol. 2, 161-174.

Gajardo, R., 1994. La vegetacion natural de Chile: clasificacion y distribucion geogr afica. Editorial Universitaria, Santiago.

Gamble, C., 1998. Palaeolithic society and the release from proximity: a network approach to intimate relations. World Archaeol. 29 (3), 426-449.

Garreaud, R.D., Vuille, M., Clement, A., 2003. The climate of the Altiplano: observed current conditions and mechanisms of past changes. Palaeogeogr. Palaeoclimatol. Palaeocol. 194, 5-22.

Gayo, E.M., Latorre, C., Jordan, C.T.E., Nester, P.L., Estay, S.A., Ojeda, K.F., Santoro, C.M., 2012. Late quaternary hydrological and ecological change in the hyperarid core of the northern Atacama desert (21S). Earth Sci. Rev. 113, 120-140.

Geyh, M.A., Grosjean, M., Núnez, L., Schotterer, U., 1999. Radiocarbon reservoir effect and the timing of the lat-Glacial/Early Holocene humid phase in the Atacama desert (northern Chile). Quat. Res. 52, 143-153.

Grosjean, M., Van Leeuwen, J.F.N., Van Der Knaap, W.O., Geyh, M.A., Ammann, B., Tanner, W., Messerli, B., Núnez, L., Valero-Garces, B.L., Veit, H., 2001. A 22000 14C year BP sediment and pollen record of climate change from Laguna Miscanti (23 S), northern Chile. Glob. Planet. Change 28, 35-51.

Haynes, G., 2013. Extinctions in North America's late glacial landscapes. Quat. Int. 285, 89- 
98.

Herrera, K.A., Ugalde, P.C., Osorio, D., Capriles, J.M., Hocsman, S., Santoro, C.M., 2015.

Variabilidad tecno-tipologica de instrumentos líticos del sitio Arcaico Temprano Ipilla 2, Puna de Arica, Chile. 2015. Chungara Rev. Antropol. Chil. 47 (1), 41-52.

Hocsman, S., 2009. Una propuesta de aproximacion teorico metodologica a conjuntos de artefactos líticos tallados. In: Barberena, R., Borrazzo, K., Borrero, L.A. (Eds.), Perspectivas Actuales en Arqueología Argentina. IMHICIHU, Buenos Aires, pp. 271302.

Hogg, A.G., Hua, Q., Blackwell, P.G., Niu, M., Buck, C.E., Guilderson, T.P., Heaton, T.J., Palmer, J.G., Reimer, P.J., Reimer, R.W., Turney, C.S.M., Zimmerman, S.R.H., 2013. SHCal13 southern hemisphere calibration, 0-50,000 years cal BP. Radiocarbon $55,1889-1903$.

Hoffman, C.M., 1985. Projectile point maintenance and typology: assessment with factor analysis and canonical correlation. In: Carr, C. (Ed.), For Concordance in Archaeological Analysis: Bridging Data Structure, Quantitative Technique, and Theory. Westport Publishers, pp. 566-612.

Houston, J., Hartley, A.J., 2003. The central Andean west-slope rainshadow and its potential contribution to the origin of hyper-aridity in the Atacama Desert. Int. J. Climatol. 23, 1453-1464.

Inizan, M.L., Reduron-Ballinger, M., Roche, H., Tixier, J., 1999. Technology and Terminology of Knapped Stone. Translated by Jehanne Feblot-Augustins. CREP, Nanterre.

Kelly, R., 1988. The three sides of a biface. Am. Antiq. 53 (4), 717-734.

Kelly, R., 1995. The Foraging Spectrum. Diversity in Hunter-gatherer Lifeways. Smithsonian Institution Press, Washington and London.

Kelly, R., 2003. Colonization of new land by hunter-gatherers: expectations and implications based on ethnographic data. In: Rockman, M., Steele, J. (Eds.), Colonization of Unfamiliar Landscapes: the Archaeology of Adaptation. Routledge, London, pp. 4459.

Klink, C., Aldenderfer, M., 2005. A projectile point chronology for the South Central Andean highlands. In: Stanish, C., Cohen, A., Aldenderfer, M. (Eds.), Advances in Titicaca Basin Archaeology 1. Costen Institute of Archaeology, Los Angeles, CA, pp. 25-54.

Lanning, E., 1967. Peru Before the Incas. Prentic-Hall, Inc, Englewood Cliffs, New Yersey. 
Latorre, C., Betancourt, J.L., Arroyo, M.T.K., 2006. Late Quaternary vegetation and climate history of a perennial river canyon in the Río Salado basin (22 S) of northern Chile. Quat. Res. 65, 450-466.

Latorre, C., Santoro, C.M., Ugalde, P.C., Gayo, E.M., Osorio, D., Salas-Egana, C., De PolHolz, R., Joly, D., Rech, J.A., 2013. Late Pleistocene human occupation of the hyperarid core in the Atacama Desert, northern Chile. Quat. Sci. Rev. 77, 19-30.

Lavallee, D., 1994. Le peuplement prehistorique de la Cordillere des Andes. Bull. la Societe Prehistorique Française 91 (4/5), 264-274.

Lavallee, D., Julien, M., Wheeler, J., Karlin, C., 1995. Telarmachay: Cazadores y Pastores Prehistoricos de los Andes (Travaux de 1 Institut Français dEtudes Andines 88). Instituto Frances de Estudios Andinos, Lima.

LeFebvre, R.P., 2004. Hakenasa: The Archaeology of a Rock Shelter in the Altiplano of Northern Chile, Graduate School Brunswik. PhD dissertation. Graduate School Brunswik, Rutgers The State University of New Yersey, New Yersey, p. 226.

Llanos, A.L., Riquelme, R.A., Herrera, E.A., Ebensperger, G., Krause Reyes, B.R.V., Sanhueza, E.M., Pulgar, V.M., Behn, C., Cabello, G., Parer, J.T., Giussani, D.A., Blanco, C.E., Hanson, M.A., 2007. Evolving in thin air: lessons from the llama fetus in the altiplano. Respir. Physiol. Neurobiol. 158, 298-306.

Luebert, F., Pliscoff, P., 2006. Sinopsis bioclimatica y vegetacional de Chile. Editorial Universitaria, Santiago.

Lyman, R.L., 1994. Vertebrate Taphonomy. Cambridge University Press, Cambridge.

Lynch, T.F., 1971. Preceramic Transhumance in the Callejon de Huaylas, Perú. Am. Antiq. $36,139-148$.

Lynch, T., 1980. Guitarrero Cave. Early Man in the Andes. Academic Press, New York.

Maldonado, A., Betancourt, J.L., Latorre, C., Villagran, C., 2005. Pollen analyses from a 50 000-yr rodent midden series in the southern Atacama Desert (2530'S). J. Quat. Sci. 20, 493-507.

Meltzer, D.J., 1981. A study of style and function in a class of tools. J. Field Archaeol. 8 (3), 313-326.

Meltzer, D.J., 2003. Lessons in landscape learning. In: Rockman, M., Steele, J. (Eds.), Colonization of Unfamiliar Landscapes: the Archaeology of Adaptation. Routledge, London, pp. 222-241.

Meltzer, D.J., 2004. Modeling the initial colonization of the Americas: issues of scale, 
demography, and landscape learning. In: Barton, C.M., Clark, G.A., Yesner, D.R., Pearson, G.R. (Eds.), The Settlement of the American Continents: a Multidisciplinary Approach to Human Biogeography. University of Arizona Press, Tucson, pp. 123137.

Moreno, A., Santoro, C.M., Latorre, C., 2009. Climate change and human occupation in the northernmost Chilean altiplano over the last ca. 11500 cal. a BP. J. Quat. Sci. 24 (4), 373-382.

Miotti, L.L., 2003. Patagonia: a paradox for building images of the first Americans during the Pleistocene/Holocene transition. Quat. Int. 109-110, 147-173.

Mujica, M.I., Latorre, C., Maldonado, A., Gonzalez-Silvestre, L., Pinto, R., De Pol- Holz, R., Santoro, C.M., 2015. Late Quaternary climate change, relict populations and presentday refugia in the northern Atacama Desert: a case study from Quebrada La Higuera (18S). J. Biogeogr. 42, 76-88.

Nelson, M., 1991. The study of technological organization. Archaeol. Method Theory 3, 57100.

Nester, P., Gayo, E., Latorre, C., Jordan, T.E., Blanco, N., 2007. Perennial stream discharge in the hyperarid Atacama Desert of northern Chile during the latest Pleistocene. Proc. Natl. Acad. Sci. 104 (50), 19724-19729.

Núnez, L., Santoro, C.M., 1988. Cazadores de la puna Seca y Salada del area Centro- Sur Andina (norte de Chile). Estud. Atacamenos 9, 11-60.

Niemeyer, H., Schiappacasse, V., 1963. Investigaciones Arqueologicas en las Terrazas de Conanoxa, Valle de Camarones (Provincia de Tarapaca). Rev. Univ. 26, 101-153.

Núnez, L., Grosjean, M., Cartagena, I., 2005. Ocupaciones humanas y Paleoambientes en la Puna de Atacama. Instituto de Investigaciones Arqueologicas and Museo Universidad Catolica del Norte, Taraxacum, San Pedro de Atacama.

Osorio, D., Jackson, D., Ugalde, P.C., Latorre, C., de Pol-Holz, R., Santoro, C.M., 2011. Hakenasa cave and its relevance for the peopling of Andean altiplano. Antiquity 85, 1194-1208.

Osorio, D., Sepúlveda, M., Castillo, C., Corvalan, M., 2016. Analisis lítico y funcionalidad de sitio de los aleros de la precordillera de Arica (centro-sur andino) durante el período Arcaico (ca. 10.000-3700 anos AP). Intersecc. Antropol. 17, 77-90.

Osorio, D., Capriles, J.M., Ugalde, P.C., Herrera, K.A., Sepúlveda, M., Gayo, E.M., Latorre, C., Jackson, D., De Pol Holz, R., Santoro, C.M., 2017. Hunter-gatherer mobility 
strategies in the high Andes of northern Chile during the late Pleistocen-early Holocene transition (ca. 11,500-9,500 cal B.P.). J. Field Archaeol. 42, 228-240.

Patty, L., Halloy, S.R.P., Hiltbrunner, E., K€orner, C., 2010. Biomass allocation in herbaceous plants under grazing impact in the high semi-arid Andes. Flora morphology, Distribution. Funct. Ecol. Plants 205, 695-703.

Petersen, L., Pellicciotti, F., 2011. Spatial and temporal variability of air temperature on a melting glacier: atmospheric controls, extrapolation methods and their effect on melt modeling, Juncal Norte Glacier, Chile. J. Geophys. Res. Atmos. 116, D23109.

Placzek, C., Quade, J., Patchett, P.J., 2006. Geochronology and stratigraphy of late Pleistocene lake cycles on the southern Bolivian altiplano: implications for causes of tropical climate change. Geol. Soc. Am. Bull. 118, 515-532.

Placzek, C., Quade, J., Betancourt, J.L., Patchett, P.J., Rech, J.A., Latorre, C., Matmon, A., Holmgren, C., English, N.B., 2009. Climate in the dry central Andes over geologic, millennial, and interannual timescales. Ann. Mo. Bot. Gard. 96, 386-397.

Pyke, G.H., Pulliam, H.R., Charnov, E.L., 1977. Optimal foraging: a selective review of theory and tests. Quart. Rev. Biol. 52, 137-154.

Placzek, C.J., Quade, J., Patchett, P.J., 2013. A 130 ka reconstruction of rainfall on the Bolivian Altiplano. Earth Plan. Sci. Lett. 363, 97-108.

Quade, J., Rech, J.A., Betancourt, J.L., Latorre, C., Quade, J., Rylander, K.A., Fisher, T., 2008. Paleowetlands and regional climate change in the central Atacama Desert, northern Chile. Quat. Res. 69, 343-360.

Rademaker, K., Hodgens, G., Moore, K., Zarrillo, S., Miller, C., Bromley, G.R.M., Lead, P., Reid, D.A., Alvarez, W.Y., Sandweiss, D., 2014. Paleoindian settlement of the highaltitude Peruvian Andes. Science 346 (6208), 466-469.

Ravines, R., 1967. El abrigo de Caru y sus relaciones tempranas con otros sitios del Sur del Perú. Nawpa Pacha 5, 39-57.

Rech, J.A., Pigati, J.S., Quade, J., Betancourt, J.L., 2003. R-evaluation of mid-Holocene deposits at Quebrada Puripica, northern Chile. Palaeogeogr. Palaeoclimatol. Palaeoecol. 194, 207-222.

Reitz, E.J., Wing, E.S., 2008. Zooarchaeology, Second Edition. Cambridge Manuals in Archaeology. Cambridge University Press, Cambridge.

Rick, J., 1980. Prehistoric Hunters of the High Andes. Academic Press, Inc., London. Rockman, M., 2003. Knowledge and learning in the archaeology of colonization. In: 
Rockman, M., Steele, J. (Eds.), Colonization of Unfamiliar Landscapes: the Archaeology of Adaptation. Routledge, London, pp. 3-24.

Sackett, J.R., 1982. Approaches to style in lithic archaeology. J. Anthropol. Archaeol. 1 (1), $59-112$

Saez, A., Godfrey, L.V., Herrera, C., Chong, G., Pueyo, J.J., 2016. Timing of wet episodes in Atacama desert over the last $15 \mathrm{ka}$. The groundwater discharge deposits (GWD) from Domeyko range at 25S. Quat. Sci. Rev. 145, 82-93.

Salvador, F., Monerris, J., Rochefort, L., 2014. Peatlands of the Peruvian Puna ecoregion: types, characteristics and disturbance. Mires Peat 15, 1-17.

Sandweiss, D.H., 2008. Early fishing societies in western south America. In: Silverman, H., Isbell, W. (Eds.), Handbook of South American Archaeology. Springer, New York, pp. 145-157.

Santoro, C.M., Latorre, C., Salas, C., Osorio, D., Ugalde, P., Jackson, D., Gayo, E.M., 2011. Ocupacion humana pleistocenica en el Desierto de Atacama. Primeros resultados de la aplicacion de un modelo predictivo interdisciplinario. Chungara Rev. de Antropol. Chil. 43, 353-366.

Sandweiss, D., McInnis, H., Burger, R.L., Cano, A., Ojeda, B., Paredes, R., Sandweiss, M., Glascock, M., 1998. Quebrada Jaguay: early maritime adaptations in South America. Science $281,1830-1832$.

Santoro, C.M., Chacama, J., 1984. Secuencia de asentamientos preceramicos del extremo norte de Chile. Estud. Atacamenos 7, 75-84.

Santoro, C., Núnez, L., 1987. Hunters of the Dry Puna and and the Salt puna in northern Chile. Andean Past. 1, 57-109.

Santoro, C.M., 1989. Antiguos cazadores de la puna (9000-6000 a.C.). In: Hidalgo, J., Schiappacasse, V., Niemeyer, H., Aldunate, C., Solimano, I. (Eds.), Culturas de Chile. Prehistoria, desde sus Orígenes hasta los Albores de la Conquista. Editorial Andres Bello, Santiago, pp. 33-55.

Santoro, C.M., Osorio, D., Ugalde, P.C., Sepúlveda, M., Cartajena, I., Standen, V.G., Gayo, E.M., Maldonado, A., Rivadeneira, M., Latorre, C., Arriaza, B., Rothhammer, F., de Souza, P., Carrasco, C., Núnez, L., 2016. Cazadores, recolectores y pescadores arcaicos del Desierto de Atacama. Entre el Pacífico y los Andes, Norte de Chile (ca. 10.000-3.700 anos a.p.). In: Aldunate, C., Falabella, F., Sanhueza, L., Hidalgo, J., Uribe, M. (Eds.), Prehistoria en Chile desde sus Primeros Habitantes hasta los Inca. 
Editorial Universitaria, Santiago, pp. 117-180.

Schittek, K., 2014. Cushion Peatlands in the High Andes of Northwestern Argentina as Archives for Palaeoenvironmental Research. Dissertationes Botanicae 412. J. Cramer in der Gebrüder Borntraeger Verlagsbuchhandlung, Stuttgart.

Sepúlveda, M., García, M., Calas, E., Carrasco, C., Santoro, C.M., 2013. Pinturas rupestres y contextos arqueologicos de la precordillera de Arica (extremo norte de Chile). Estud. Atacamenos 46, 27-46.

Sepúlveda, M., Saintenoy, T., Cornejo, L., Dudognon, C., Espinoza, F., Guerrero- Bueno, Z., Cerrillo-Cuenca, E., 2017. Rock art painting and territoriality in the precordillera of Arica, northern Chile (South Central Andes). Spatial and archaeological approaches for the naturalistic tradition. Quat. Int. http:// dx.doi.org/10.1016/j.quaint.2017.02.005 (in press).

Shott, M.J., 1996. An exegesis of the curation concept. J. Anthropol. Res. 52 (3), 259-280.

Shott, M.J., Ballenger, J.A., 2007. Biface reduction and the measurement of Dalton curation: a southeastern United States case study. Am. Antiq. 72 (1), 153-175.

Squeo, F.A., Warner, B.G., Aravena, R., Espinoza, D., 2006. Bofedales: high altitude peatlands of the central Andes. Rev. Chil. Hist. Nat. 79, 245-255.

Troll, C., 1958. Las Culturas Superiores Andinas y el Medio Geografico (traduccion de Carlos Nicholson). Instituto de Geografía, Facultad de Letras, Universidad Nacional Mayor de San Marcos, Lima.

Veit, H., May, J.H., Madella, A., Delunel, R., Schlunegger, F., Szidat, S., Capriles, J.M., 2016. Palaeo-geoecological significance of Pleistocene trees in the Lluta valley, Atacama desert. J. Quat. Sci. 31, 203-213.

Villagran, C., Arroyo, M.T.K., Marticorena, C., 1983. Efectos de la Desertizacion en la Distribucion de la Flora Andina de Chile. Rev. Chil. Hist. Nat. 56, 137-157.

Vuille, M., Keimig, F., 2004. Interannual variability of summertime convective cloudiness and precipitation in the central Andes derived from ISCCP-B3 data. J. Clim. 17, 3334-3348.

West, J.B., 2004. The physiologic basis of high-altitude diseases. Ann. Intern. Med. 141, 789800.

Wiessner, P., 1983. Style and social information in Kalahari San projectile points. Am. Antiq. 48 (2), 253-276.

Winchkler, G., 2006. Terminología del Analisis Lítico en Arqueología. Diccionario de uso 
para la Descripcion de Objetos Líticos. http://www.winchkler.com.ar/.

Wobst, H.M., 1999. Style in archaeology or archaeologists in style. In: Chilton, E.S. (Ed.), Material Meanings: Critical Approaches to the Interpretation of Material Culture. Univ. Utah Press, Salt Lake City, pp. 118-132. 


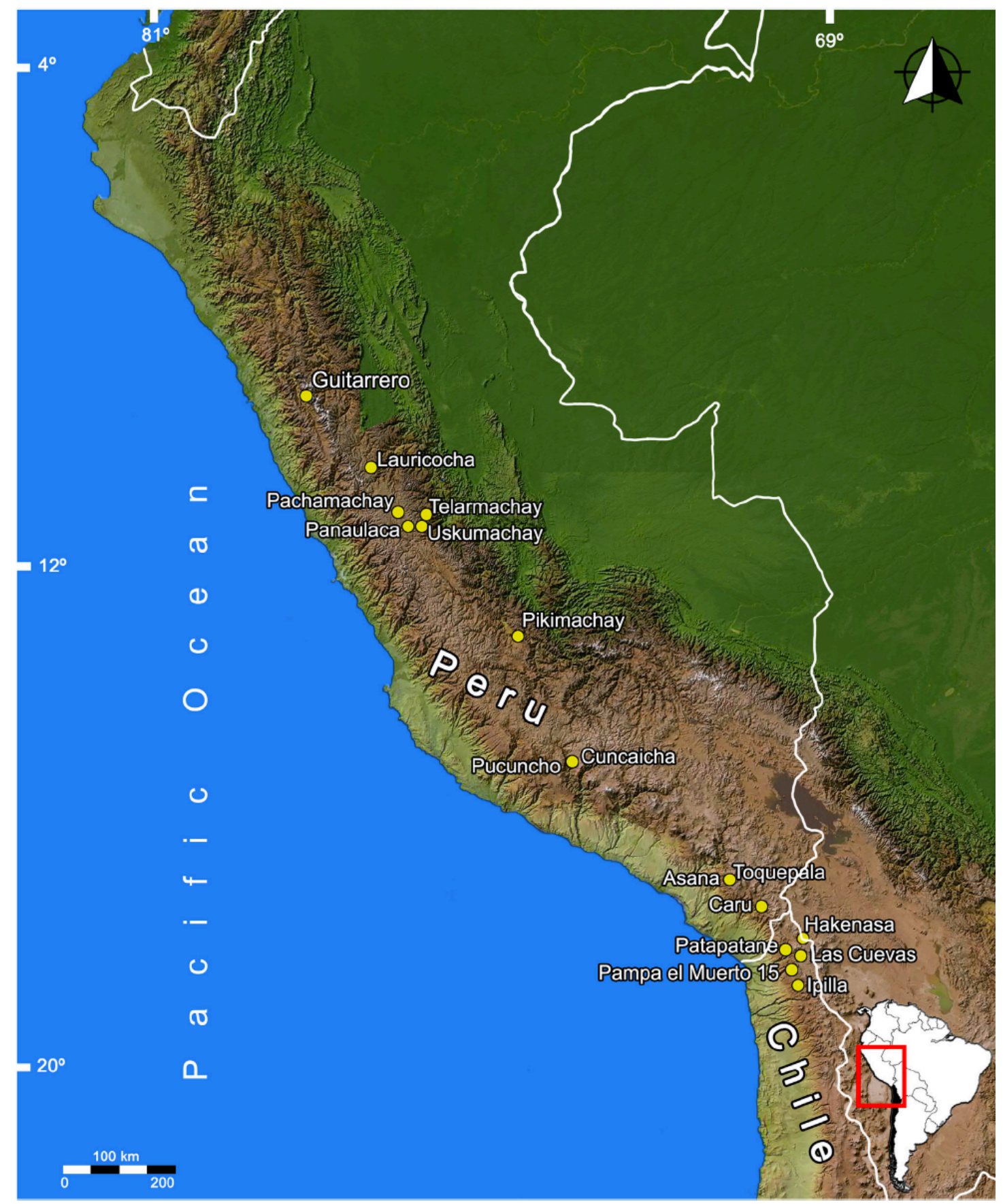

Fig. 1. High Andes Central Peru and Dry Puna Pleistocen-Holocene archaeological sites. 


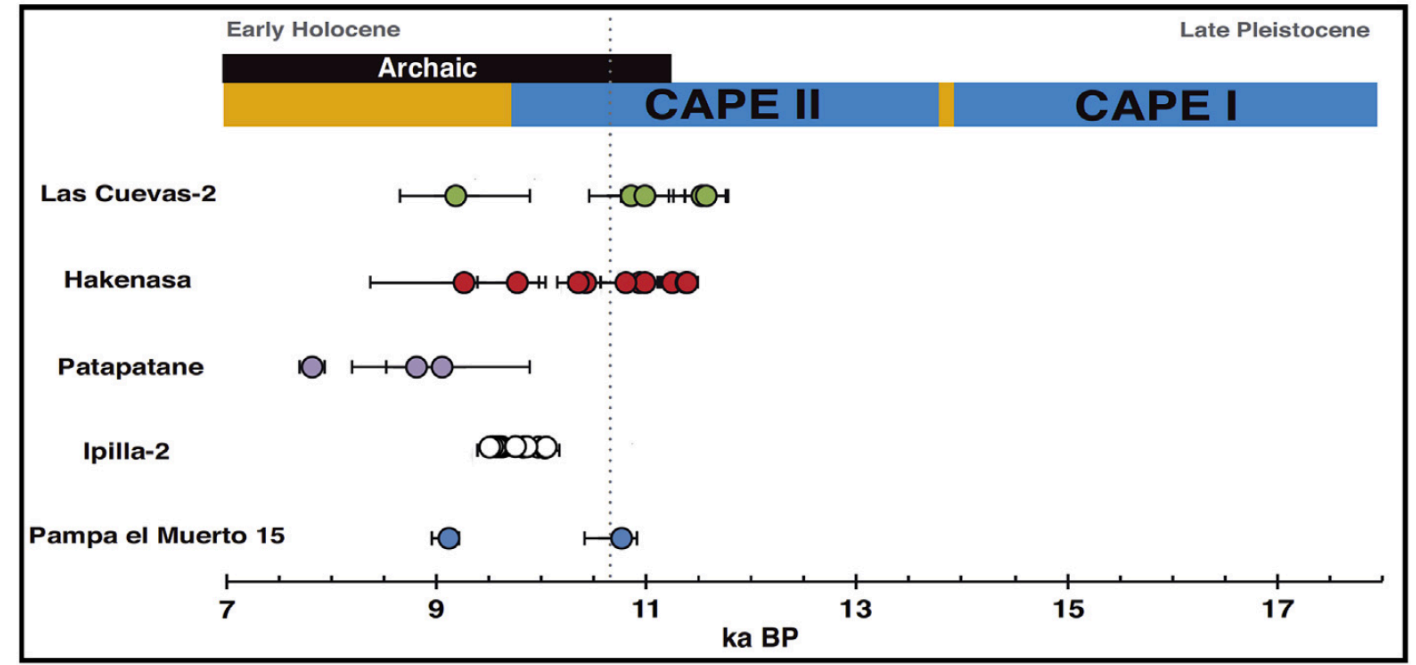

Fig. 2. Chronological relationship between calibrated ages for each archeological site considered in this study and inferred paleoclimate conditions along the western Andean slope in the interval 7-18 ka BP. Light blue bars represent Central Andean Pluvial Event (CAPE) phases, while orange bars denote negative hydroclimate conditions. Vertical dashed line delineates the Pleistocen-Holocene transition. Archeological dates were calibrated in Calib 7.0.4 by using the SHCAL 13 calibration curve.

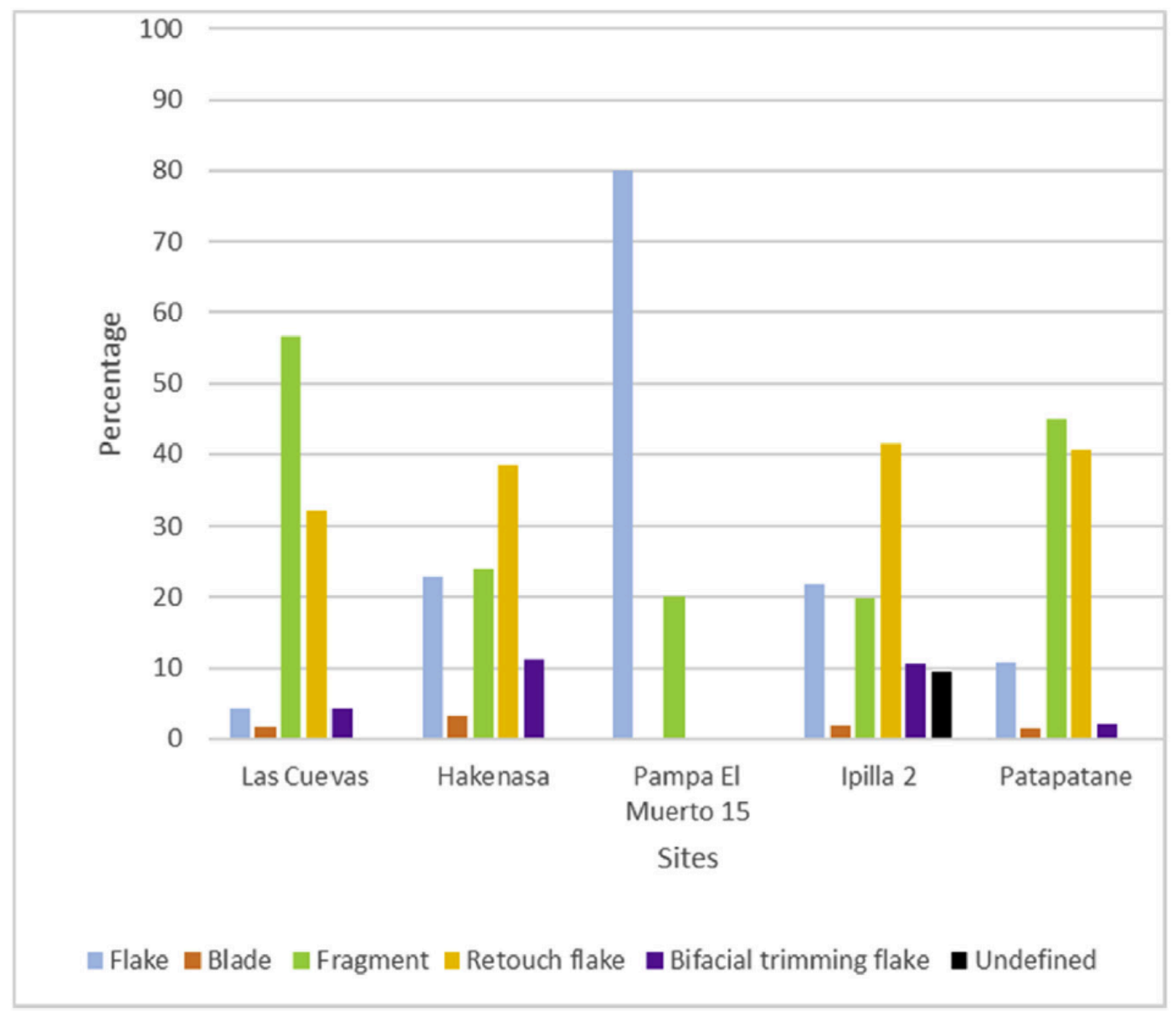

Fig. 3. Percentage of debitage products identified at the different Dry Puna sites of northern Chile. 
1

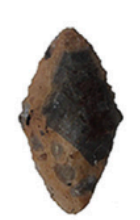

2

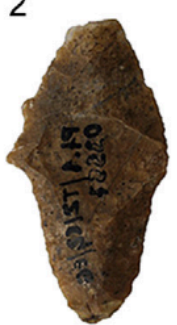

3

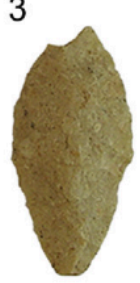

4

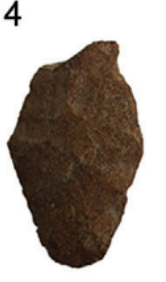

5
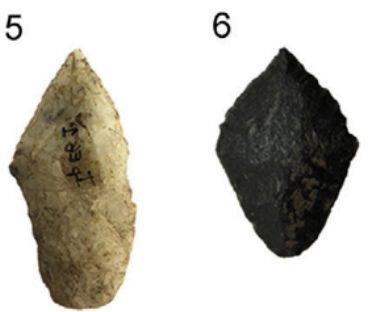

7

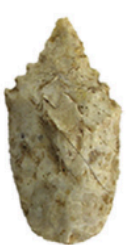

8

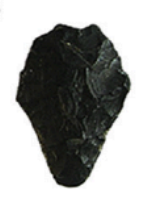

9

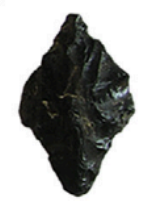

10

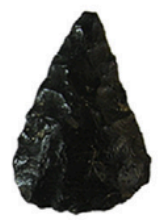

-
11

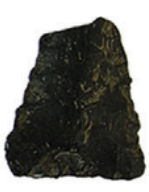

15

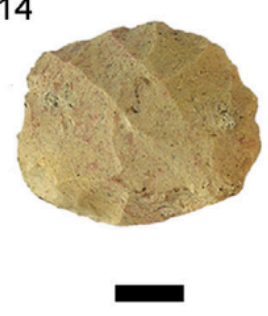

18

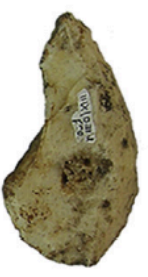

19

12

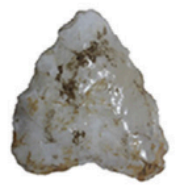

16

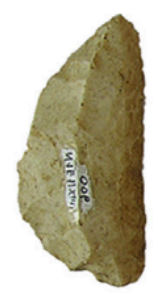

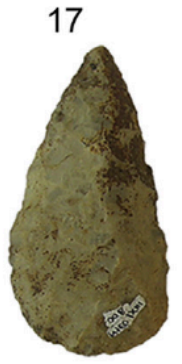
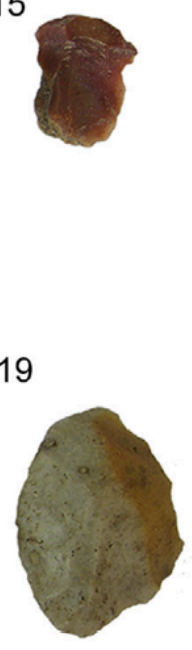

Fig. 4. Lithic tools from the studied sites. Stemmed projectile points with shoulders "Patapatane type": $(1,2,6)$, Patapatane, (3) Hakenasa $(4,5,7)$ Ipilla. Tetragonal projectile points: $(8,9)$ Hakenasa. Unstemmed triangular projectile points with convex base $(10$ Hakenasa), straight base (11 Hakenasa), and concave base (12 Patapatane). Hakenasa scrapers $(13,14,15)$, Hakenasa sidescrapers $(16,17,18,19)$. 

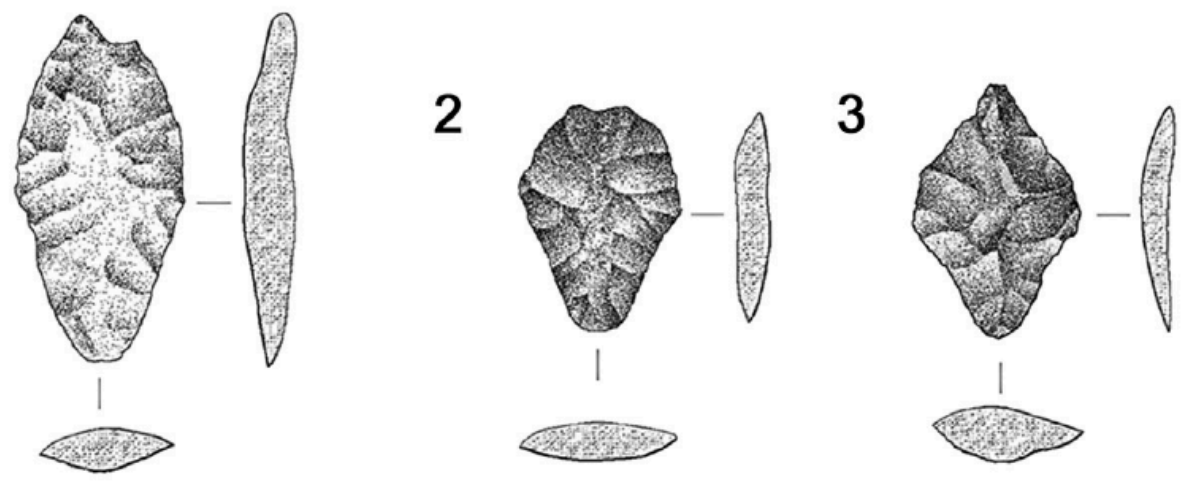

4

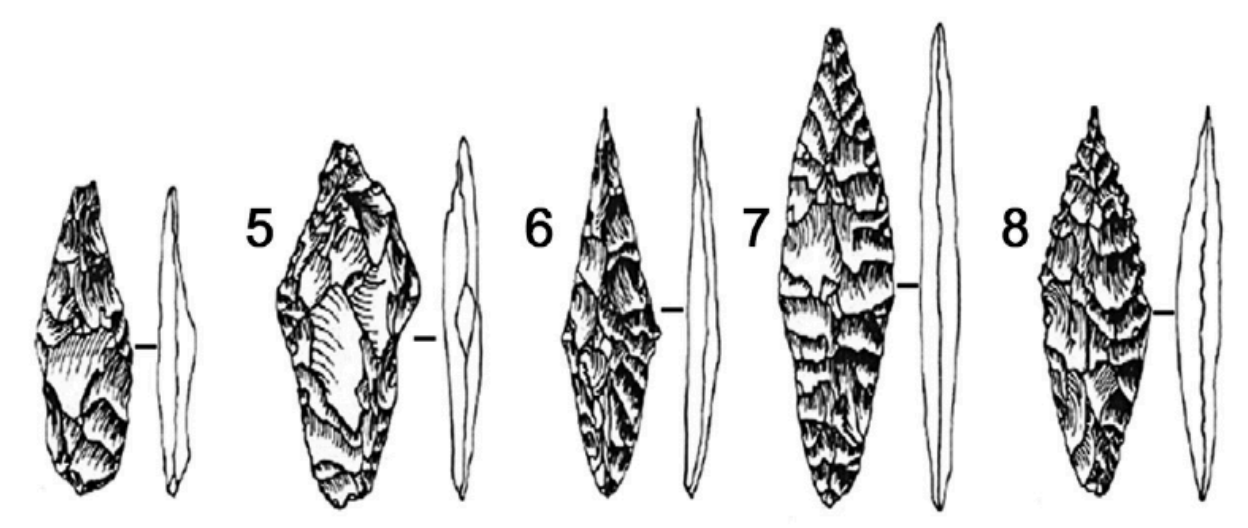

9
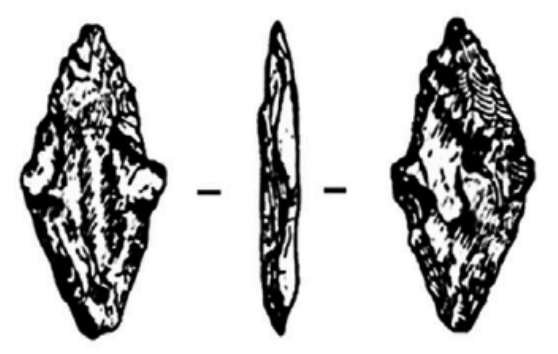

10
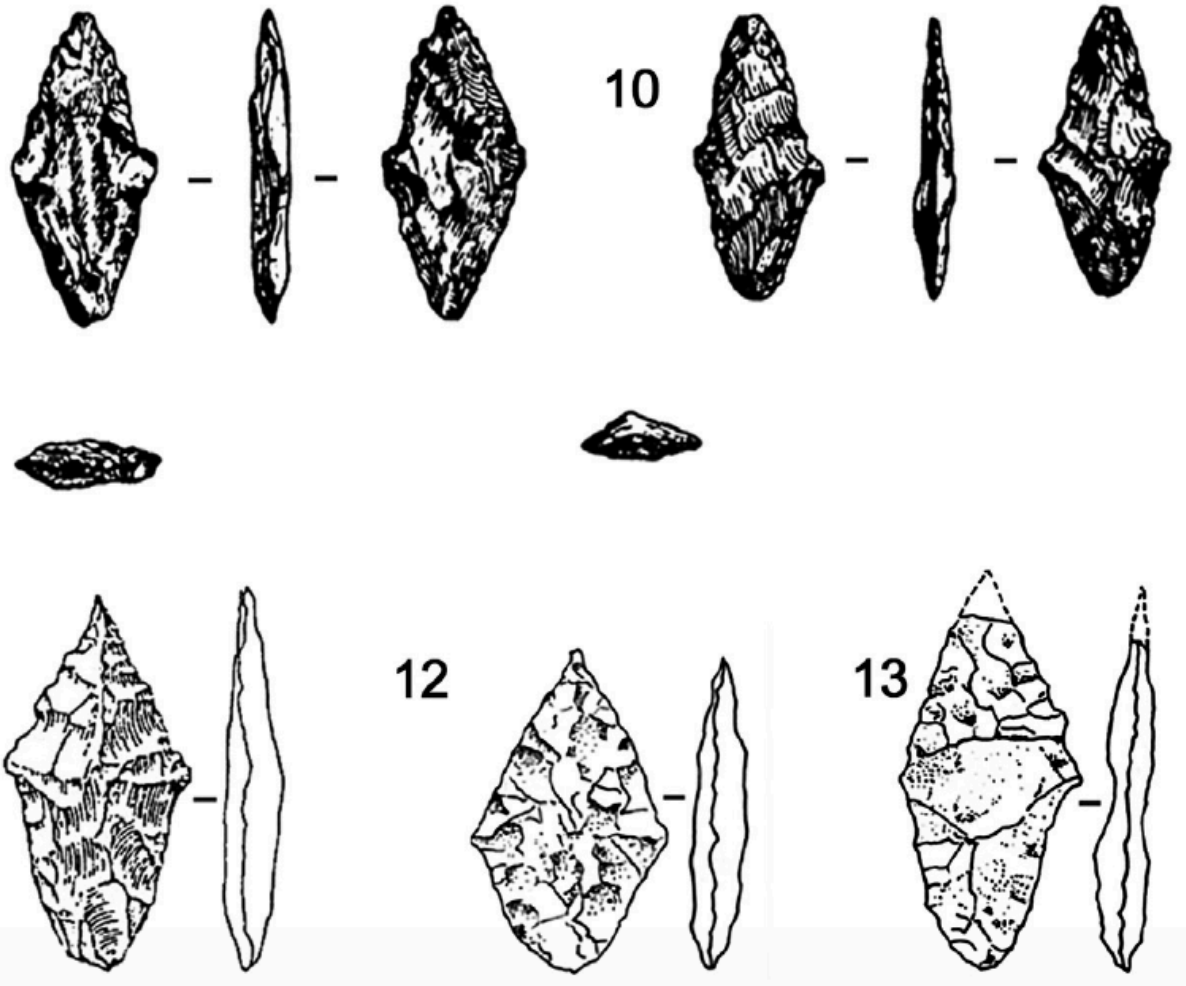

Fig. 5. Similar projectile points types from different sites of the Andean highlands. (1-3) Hakenasa (after Osorio et al., 2011: Fig. 7); (4-8) Asana (after Aldenderfer, 1998: Fig. 6.24); (9-10) Caru (after Ravines, 1967: Fig. 26); (11) Telarmachay (after Lavallee, 1994: Fig. 5); (12-13) Patapatane (after Santoro and Nunez, 1987: Fig. 5). 
Table 1. 41 AMS radiocarbon dates for archeological sites discussed in the text. All radiocarbon dates were calibrated using CALIB 7.0.4 at 2-sigma with the Southern Hemisphere correction.

\begin{tabular}{|c|c|c|c|c|c|c|c|c|}
\hline Site & Level & Lab-Code & ${ }^{14} \mathrm{C}$ yr BP & $\begin{array}{l}\text { Age } \\
\text { (cal } \\
\text { yrs } \\
\text { BP) }\end{array}$ & $\begin{array}{l}\text { Lower cal } \\
\text { range BP }\end{array}$ & $\begin{array}{l}\text { Upper cal } \\
\text { range BP }\end{array}$ & $\begin{array}{l}\text { Material } \\
\text { dated }\end{array}$ & Reference \\
\hline Hakenasa & Level 13 & Beta-187535 & $9580 \pm 40$ & 10,890 & 10,700 & 11,090 & Charcoal & LeFebvre 2004 \\
\hline Hakenasa & Level 14 & UCIAMS-145003 & $9655 \pm 40$ & 10,940 & 10,770 & 11,160 & Camelid tooth & Osorio et al. in press \\
\hline Hakenasa & Level 13 & UCIAMS-77761 & $9830 \pm 40$ & 11,210 & 11,150 & 11,260 & Charcoal & Osorio et al., 2011 \\
\hline Hakenasa & Level 13 & UCIAMS-77762 & $9975 \pm 40$ & 11,330 & 11,240 & 11,600 & Charcoal & Osorio et al., 2011 \\
\hline Hakenasa & Level 13 & UGAMS-2953 & $9980 \pm 40$ & 11,340 & 11,240 & 11,600 & Charcoal & Osorio et al., 2011 \\
\hline Hakenasa & Level 12 & Beta-187534 & $9520 \pm 70$ & 10,760 & 10,560 & 11,090 & Charcoal & LeFebvre 2004 \\
\hline Hakenasa & Level 11 & Beta-187533 & $9260 \pm 60$ & 10,380 & 10,240 & 10,550 & Charcoal & LeFebvre 2004 \\
\hline Hakenasa & Level 11 & Beta- 187532 & $9170 \pm 70$ & 10,310 & 10,190 & 10,500 & Charcoal & LeFebvre 2004 \\
\hline Hakenasa & Level 10 & Beta-187531 & $8789 \pm 60$ & 9740 & 9540 & 10,120 & Charcoal & LeFebvre 2004 \\
\hline Hakenasa & Level 23 & $\mathrm{I}-13287$ & $8340 \pm 300$ & 9230 & 8460 & 10,120 & Charcoal & Santoro and Núnez 1987 \\
\hline Ipilla 2 & 15 & UGAMS-4588 & $8510 \pm 30$ & 9490 & 9440 & 9530 & Charcoal & Santoro et al., 2011 \\
\hline Ipilla 2 & N1-1 8 & UCIAMS-77765 & $8600 \pm 40$ & 9530 & 9470 & 9600 & Charcoal & Santoro et al., 2011 \\
\hline Ipilla 2 & N1-1 7 & UCIAMS-77764 & $8635 \pm 40$ & 9550 & 9490 & 9660 & Charcoal & Santoro et al., 2011 \\
\hline Ipilla 2 & N1-1 6 & UCIAMS-84348 & $8675 \pm 25$ & 9580 & 9530 & 9670 & Charcoal & Santoro et al., 2011 \\
\hline Ipilla 2 & N1-0 10 & UCIAMS-77767 & $8690 \pm 40$ & 9600 & 9530 & 9700 & Charcoal & Santoro et al., 2011 \\
\hline Ipilla 2 & N1-1 9 & UCIAMS-77766 & $8695 \pm 40$ & 9600 & 9530 & 9730 & Charcoal & Santoro et al., 2011 \\
\hline Ipilla 2 & N1-0 13 & UCIAMS-77770 & $8695 \pm 40$ & 9600 & 9530 & 9730 & Charcoal & Santoro et al., 2011 \\
\hline Ipilla 2 & Ipilla 2/S4-0/1 & UCIAMS-165635 & $8700 \pm 70$ & 9640 & 9520 & 9890 & Charcoal & This study \\
\hline Ipilla 2 & S5-0/2B & UCIAMS-165632 & $8725 \pm 25$ & 9620 & 9540 & 9700 & Charcoal & This study \\
\hline Ipilla 2 & N1-0 11 & UCIAMS-77768 & $8730 \pm 35$ & 9630 & 9540 & 9760 & Charcoal & Santoro et al., 2011 \\
\hline Ipilla 2 & $\mathrm{~S} 4-0 / 2 \mathrm{~A}$ & UCIAMS-165633 & $8780 \pm 25$ & 9700 & 9560 & 9890 & Charcoal & This study \\
\hline Ipilla 2 & Exposed profile & CAMS-124594 & $8785 \pm 30$ & 9710 & 9560 & 9890 & Charcoal & Santoro et al., 2011 \\
\hline Ipilla 2 & S4W1/2B-C & UCIAMS-165636 & $8820 \pm 25$ & 9780 & 9630 & 10,110 & Charcoal & This study \\
\hline Ipilla 2 & S5-0/2B-C & UCIAMS-165638 & $8820 \pm 25$ & 9780 & 9630 & 10,110 & Charcoal & This study \\
\hline Ipilla 2 & N1-0 12 & UCIAMS-77769 & $8825 \pm 40$ & 9800 & 9560 & 10,120 & Charcoal & Santoro et al., 2011 \\
\hline Ipilla 2 & Exposed profile & CAMS-124595 & $8840 \pm 30$ & 9820 & 9660 & 10,130 & Charcoal & Santoro et al., 2011 \\
\hline Ipilla 2 & S4-0/2- & UCIAMS-165639 & $8845 \pm 25$ & 9830 & 9680 & 10,120 & Charcoal & This study \\
\hline Ipilla 2 & Exposed profile & CAMS-124596 & $8845 \pm 30$ & 9830 & 9680 & 10,130 & Charcoal & Santoro et al., 2011 \\
\hline Ipilla 2 & S4W1/2C & UCIAMS-165634 & $8890 \pm 25$ & 9960 & 9750 & 10,160 & Charcoal & This study \\
\hline Ipilla 2 & S4W1/2- & UCIAMS-165637 & $8940 \pm 30$ & 10,030 & 9900 & 10,180 & Charcoal & This study \\
\hline Las Cuevas 2 & T2-IVC & Beta-298938 & $10,040 \pm 70$ & 11,490 & 11,250 & 11,760 & Charcoal & Santoro et al., 2011 \\
\hline Las Cuevas 2 & E8/IVC & UCIAMS-165646 & $10,070 \pm 30$ & 11,520 & 11,330 & 11,720 & Charcoal & Osorio et al. in press \\
\hline Las Cuevas 2 & Level 11 & I-13128 & $8270 \pm 250$ & 9160 & 8460 & 9700 & Charcoal & Santoro and Chacama 1984 \\
\hline Las Cuevas 2 & Level 13 & $\mathrm{I}-12835$ & $9540 \pm 160$ & 10,810 & 10,300 & 11,210 & Charcoal & Santoro and Chacama 1984 \\
\hline Las Cuevas 2 & T2-IVA & Beta-298937 & $9630 \pm 70$ & 10,940 & 10,710 & 11,170 & Charcoal & Osorio et al. in press \\
\hline $\begin{array}{l}\text { Pampa El } \\
\text { Muerto } 15\end{array}$ & Level 9 & Beta-335686 & $8190 \pm 40$ & 9090 & 9000 & 9250 & Burned bone & Osorio et al., 2016 \\
\hline $\begin{array}{l}\text { Pampa El } \\
\text { Muerto } 15\end{array}$ & Level 13 & Beta-319884 & $9510 \pm 50$ & 10,720 & 10,570 & 11,070 & Burned bone & Osorio et al., 2016 \\
\hline Patapatane & Level G & Beta-238853 & $7010 \pm 40$ & 7800 & 7690 & 7930 & Charcoal & Santoro et al., 2011 \\
\hline Patapatane & Level 20 & Beta-43019 & $7970 \pm 110$ & 8780 & 8460 & 9070 & Charcoal & Santoro et al., 2005 \\
\hline Patapatane & Level J & $\mathrm{I}-12837$ & $8160 \pm 340$ & 9030 & 8210 & 9890 & Charcoal & Santoro and Chacama 1984 \\
\hline Patapatane & Level J & Beta-238852 & $8440 \pm 80$ & 9400 & 9140 & 9540 & Charcoal & Santoro et al., 2011 \\
\hline
\end{tabular}


Table 2. Site description and frequencies of the studied materials.

\begin{tabular}{|l|l|l|l|l|l|l|}
\hline Site & $\begin{array}{l}\text { Elevation } \\
\text { (masl) }\end{array}$ & $\begin{array}{l}\text { Camp } \\
\text { category }\end{array}$ & $\begin{array}{l}\text { Studied } \\
\text { occupation } \\
\text { level }\end{array}$ & $\begin{array}{l}\text { Excavated } \\
\text { area } \mathbf{( m}^{\mathbf{2}} \mathbf{)}\end{array}$ & Lithics & $\begin{array}{l}\text { Animal } \\
\text { bones }\end{array}$ \\
\hline Las Cuevas & 4485 & $\begin{array}{l}\text { Rock } \\
\text { shelter }\end{array}$ & IVc & 3 & 357 & 6 \\
\hline Hakenasa & 4100 & Cave & $13-14$ & 6 & 1284 & 2849 \\
\hline $\begin{array}{l}\text { Pampa El } \\
\text { Muerto 15 }\end{array}$ & 3174 & $\begin{array}{l}\text { Rock } \\
\text { shelter }\end{array}$ & 13 & 1.5 & 26 & 140 \\
\hline Ipilla 2 & 3400 & $\begin{array}{l}\text { Open-air } \\
\text { site }\end{array}$ & $6-12$ & 1.5 & 1888 & 288 \\
\hline Patapatane & 3800 & Cave & $\mathrm{J}$ & 7 & 912 & 586 \\
\hline
\end{tabular}

Table 3. Provenience of the main raw materials categories identified in the studied sites.

\begin{tabular}{|l|l|l|l|}
\hline Sites & Siliceous & Obsidian & Basalt \\
\hline Las Cuevas & Extra-Local & Probably Local & Extra-local \\
\hline Hakenasa & Extra-Local & Probably Local & Extra-local \\
\hline Pampa El Muerto 15 & Probably Local & Extra-local & Extra- local \\
\hline
\end{tabular}

Table 4. Percent of cortex present in the dorsal surface of the debitage products by site.

\begin{tabular}{|l|l|l|l|l|l|}
\hline $\begin{array}{l}\text { Cortex } \\
\text { Percent }\end{array}$ & Las Cuevas & Hakenasa & $\begin{array}{l}\text { Pampa El } \\
\text { Muerto 15 }\end{array}$ & Ipilla & Patapatane \\
\hline No cortex & 94.92 & 81.54 & 100 & 98.5 & 98.5 \\
\hline Less $<50$ & 4.52 & 15.75 & & 1.02 & 1 \\
\hline More $>50$ & 0.56 & 2.73 & & 0.27 & 0.2 \\
\hline Full cortex & & & & 0.21 & 0.2 \\
\hline
\end{tabular}

